\title{
Incorporating Practices of Publicness in Kuwaiti Parks. Chai Ithahha, Cricket, Diwaniya, and Malls
}

\author{
Weaam Alabdullah \\ The University of Virginia, United States of America \\ wha5dp@virginia.edu
}

\begin{abstract}
This paper focuses on practices of publicness in Kuwait that do not necessarily fall under accepted discourses of public space, highlighting the importance of incorporating such practices within the existing literature as they affect landscape architecture. The practices include chai ithahha (women's morning tea), diwaniya (predominantly men's gathering), cricket games played by South Asian men, and mall outings. I suggest using these practices in the design of parks at a time of increasing privatization. While these practices enhance social connectivity in Kuwait and highlight political demands as in the case of the diwaniya and chai ithahha, I contend that these examples have limitations because they take place in exclusive settings, affecting access and appearance of certain publics based on class, gender, nationality, and location. The mall is a landscape and one can argue that malls can incorporate spaces for diwaniya and chai ithahha gatherings, and perhaps even cricket courts. Yet, there is something about the tactility of the landscape that is unsatisfied by the mall. The mall is meeting a certain need but is insufficient, as it remains an exclusive, private, and closed space. Parks stand as complex cultural spaces of representation and risk and they offer the best opportunity for an inclusive atmosphere. The practices highlight a potential for parks in dealing with privatization and segregation. Embracing and reinterpreting these practices in more inclusive parks may lead to the appearance and representation of more publics in spaces tailored to a place's identity and people's needs. This could mean introducing multiple programs in one space, like gathering spaces for a diwaniya and chai ithahha, and sports areas, within diverse urban settings, while also focusing on the microscale of design elements like seating. This paper concludes that public parks which embrace such practices begin to respond to the needs of society with all its complexity, becoming a terrain for fostering both community engagement and placemaking.
\end{abstract}

Keywords: public space, expansion of publics, parks, cultural landscapes and sports

To cite this article:

Alabdullah, W. (2020). Incorporating Practices of Publicness in Kuwaiti Parks. Chai Ithahha, Cricket, Diwaniya, and Malls, The Journal of Public Space, 5(I), 95-I I0, DOI I0.3289I/jps.v5iI.I 253

This article has been double blind peer reviewed and accepted for publication in The Journal of Public Space. (c) (i) \$ This work is licensed under a Creative Commons Attribution - Non Commercial 4.0 International License https://creativecommons.org/licenses/by-nc/4.0/ 


\section{Introduction}

Practices of publicness differ all over the world and in many instances, they allow similarities and differences between multiple publics to arise. Within the Kuwaiti context, four very different practices of publicness - the diwaniya, chai ithahha, mall gatherings, and cricket games - become very important and worthy of study for future public park projects. The four activities all include and exclude certain publics and thus have benefits and limitations. Common public space discourses do not acknowledge such practices. By examining these activities, I am highlighting the importance of focusing on these practices within the literature because of the practices' potential in placemaking in public parks. I aim to better understand how multiple publics in Kuwait may begin to benefit from the incorporation of the practices in future parks at a time of increased privatization. Currently, the four practices take place in private settings apart from the cricket games and thus allow and/or inhibit certain publics and actions in their current existence. This paper is less about the practices in Kuwait, and more about putting into question practices ignored from the literature, to see how they potentially lead to more inclusive and culturally sensitive parks.

Chai ithahha (women's morning tea), diwaniya ( $p l$. diwaween or diwaniyaat) (men's evening gatherings), cricket games, and mall gatherings depict practices of publicness that are unique to the Kuwaiti context. These examples inherently combine an activity and a particular space. The cricket games take place on public lots that are yet to be developed. Although the other examples facilitate public interactions, they exist in private spaces. This resonates with Jürgen Habermas' (1962) notion of the public sphere which allows one to imagine public life occurring in private spaces. Each of the four practices has different origins, meanings, spaces, and crowds. However, they share the fact that they are practiced by people in Kuwait regularly, thus requiring attention. The social and political impacts of the four activities also deserve attention. One example that speaks of gender roles in Kuwait is chai ithahha, which is a women-only gathering that happens in private residences or nowadays in cafes and restaurants. Another powerful example is the diwaniya, which is mostly a space for men to gather and talk, but nowadays they are opening up to women. Socially, both private gatherings, at different times of day, allow men and women to argue and speak about both important and rather trivial issues. Cricket games allow migrant workers to celebrate their own identity within a completely different cultural context during the early mornings and late afternoons. The mall allows people to mingle with and flirt with people of different backgrounds, and maybe even meet significant others throughout the day. While the practices may seem apolitical, the conversations taking place in private gatherings speak to local and global politics; diwaween can even impact who wins a seat in parliament. While the cricket games do not inherently deal with politics, they highlight a tactic in fighting against the social order in Kuwait, which prioritizes Kuwaitis over immigrants. South Asian workers don't have public spaces to call their own, leading them to set up impromptu cricket spaces to reclaim their identity through active participation in public space.'

Yet, one must also understand the limitations of the four practices due to their existence in exclusive and private settings, and especially concerning the separation of multiple publics. I use the word publics to try and get away from the notion of a single

\footnotetext{
' Asians make up the majority of the population.
} 
public as this excludes many social groups, or publics. The Ninth session of the World Urban Forum highlighted the problems of increasing privatization leading to greater inequities, barriers, and segregation of different social groups (Bravo, 2018.) While the four examples enrich social connectivity, and some preserve cultural heritage and influence the country's politics, they reveal problems of exclusion, segregation, and social stratification. The affiliated spaces are private (apart from the cricket spaces) and homogeneous. I must clarify that these practices are not wrong or bad, and especially when it comes to the gendered aspect. While in other contexts one would expect that these conversations could be had in a mix-gendered setting, the historical, religious, and cultural aspects make this gender separation appropriate. In Kuwait, numerous activities continue to take place in single-sex spaces including public schooling. It would be very commanding to expect all men and women to gather and debate in this eclectic context which has both conservative and liberal crowds. Rather, one must begin to understand the dynamics and activities of this place and incorporate them in designs. Designed parks from such a perspective would allow the representation of more publics in a more culturally sensitive manner. There is space for landscape architecture within these practices and this paper questions what such public spaces that preserve place identity can look like.

Beginning with the premise that public parks stand as complex cultural spaces (Czerniak \& Hargreaves, 2007), and spaces of representation and risk (Meyer 2007), I argue that reinterpreting these practices within the literature and incorporating them in parks may lead to the appearance of a greater diversity of publics, enriched public spaces, and more successful urban placemaking. This suggests more balanced and equitable park design. This effort nurtures social connectivity, respects different cultures, and highlights hidden tensions in society, allowing people to see and confront their differences. In the end, the paper highlights two things: the importance of incorporating such practices of publicness within public space literature, and the role of parks in democratic/semidemocratic societies in expanding publics and allowing for co-existence. While some may question incorporating mostly private practices in public space, especially when arguing against privatization, I argue that the selected practices are worthy of study because they both facilitate the needs of people in Kuwait and placemaking at times of increasing privatization and capitalism.

Methodologically, this paper employs critical theories on public space and parks, writings on Kuwait's practices of publicness, field observations, and secondary sources including newspaper articles and photographs. The ethnographic research took place in Kuwait, and briefly Dubai, during the summers of 2017, 2018, and 2019.

\section{Practices of publicness Chai ithahha}

Several scholars have studied the relationship between women, space and politics in Kuwait (Al-Mughni 2000; Alenazy 2007; Alsayer 20I4; Al-Ansari 20I6). However, morning tea, or chai ithahha, is an understudied social and political ritual for Kuwaiti 
women. ${ }^{2}$ In this practice, women traditionally get together for light snacks and tea in private residences. Chai refers to tea and ithahha refers to the morning time. This takes place on weekdays around 10 am for an hour or two and the number of women varies in each setting. These gatherings typically involve women who do not work outside of the household. Interestingly, a television program hosted by female hosts titled 'Chai Ithahha' broadcasts live on weekdays at I0 am on the national Kuwait Television Channel I (Chai Ithahha, 2019). Officially labeled as a 'social program,' it covers topics including medicine, psychology, finance, art, literature and more. The origins of chai ithahha are unclear, but according to Fouad Al-Mogahwi, a researcher of Kuwaiti heritage, this ritual started centuries ago (Al-Soula, 20I3). Due to changing times, these gatherings take place nowadays in coffee shops or restaurants, as well as in private residences (AI-Soula, 2013), which speaks to Habermas' (I962) conceptualization of the public sphere in coffee shops. Rituals may adjust with time, suggesting that the spaces that support them must adapt as well.

Moreover, chai ithahha started as a social ritual but has taken a more political turn at a time when society discusses and monitors political events locally and globally (Atifa, 2013). This is true especially in the aftermath of political events like the Arab Spring (Atifa 20I3). Nouriya Al-Kharafi states that the political overshadows the social in these get-togethers, while still stressing the importance of social networking through morning tea sessions (Atifa, 20I3). This resembles London coffee shops of $17^{\text {th }}$ century England that were privately owned but publicly used to have political debates (Cowan, 2005). While chai ithahha gatherings may seem, at first glance, like superficial slander sessions, they operate as spaces of meaningful exchange because they are a place in which women, who are not actively engaged in the public sphere are reclaiming their political voices. Unemployed women are still an important part of civil society and this morning tea ritual emphasizes that.

\section{Diwaniya}

The diwaniya, which is both a practice and space, started as a gathering for men to socialize and converse. The term diwaniya speaks to both the physical space of the congregation and the practice of gathering itself (Clemens, 2016). The term comes from the word divan in Persian, meaning a formal council room. Numerous scholars study the social and political aspects of the diwaniya and its importance in Kuwaiti society (AlJassar, 2009; Alhabib, 2009; Alhajeri, 2010; Clemens, 2016; Almutairi \& Kruckerberg, 2019). Some diwaween are more public than others and this responds to the nature of each diwaniya owner or their social and/or political position. The diwaniya emerged in the $19^{\text {th }}$ century, taking multiple shapes and forms from a single room in a house with a private entryway, to an elaborate standalone building. Also, affluence is directly proportional to the scale of the spaces. Diwaween may occur daily or less frequently. Clemens Chay describes the diwaniya "as 'a given' in everyday Kuwaiti life" (Clemens, 2016: I), emphasizing the routine aspect of this practice, and a ritual that is "reinforced in the architecture of the courtyard houses" (Clemens, 2016: 8). A typical modern Kuwaiti home most often includes a diwaniya or gathering space of some sort with separate access as to respect the privacy of the home. This allows men, and nowadays

\footnotetext{
${ }^{2}$ Most of the sources used in this section are based on a newspaper article titled "File of the Week" because it is a much understudied subject matter with limited sources.
} 
women, to invite people to talk, argue and commiserate over sustenance. Figure I showcases a men's diwaniya in Mishref, which is an upper-middle class residential neighbourhood.

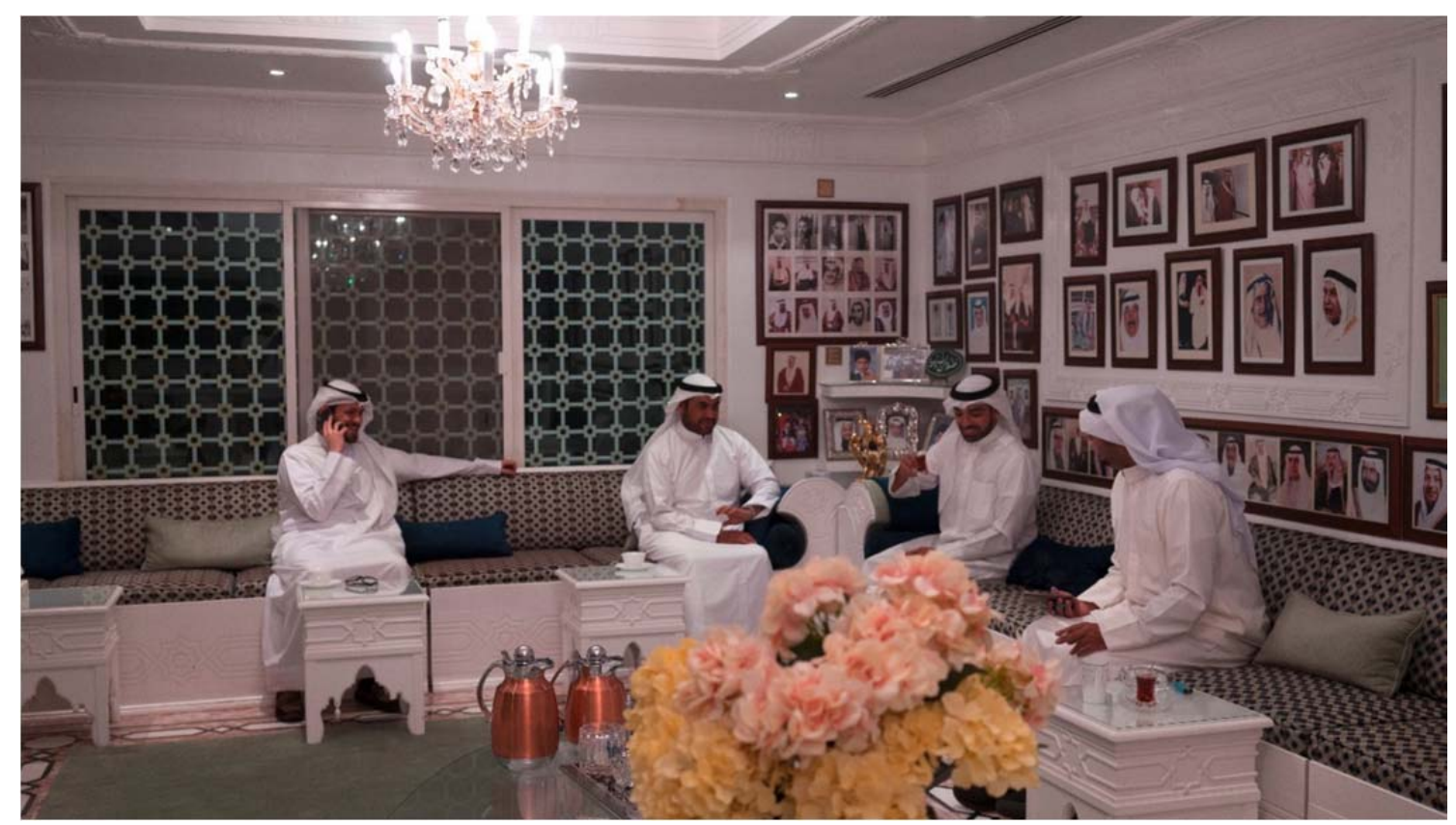

Figure I. AlQaud Family Diwaniya, Mishref, Kuwait (Photographed by Mohammed AIKouh)

Politics play a major role in the diwaniya. Several scholars focus on the diwaniya as both a social and political space in the Kuwaiti landscape (Alhajeri, 2010; Clemens, 2016; Almutairi \& Kruckerberg, 2019). Historically, Kuwaiti politics took place in the diwaniya, especially the Monday diwaween or 'diwaween ilathnain' (Alhajeri, 20I0; Clemens, 2016.) These started in the 1980s as a way for people and parliamentary members "to convey their absolute rejection of the resignation of the cabinet and the dissolution of parliament" (Alhajeri, 2010: 37). One may recognize the diwaniya as an informal political space because it deals with public opinions, which in turn affected the formal parliamentary field. Members running for parliament undertake diwaniya-hopping to make sure they reach a larger voting audience, which in turn impacts who succeeds. Thus within the diwaniya, politicians build relationships to navigate political life. Hannah Arendt states that "wherever men are together in the manner of speech and action" (Arendt, 1958: 199), democracy takes place. The diwaniya stands as a democratic space that goes beyond people's social lives.

Even though this space was historically associated with men, the diwaniya today caters to all genders and ages. The mechanisms through which one is included, or for that matter excluded, vary from one setting to another. For instance, in more liberal neighborhoods, it is normal for women, especially those interested in politics, to attend and host diwaween, thereby diversifying diwaniya crowds. However, while women and men may attend some diwaween together, many are still segregated. Monday crowds vary in age, as anyone eligible to vote may choose to attend, in particular, ones hosted 
by campaigning politicians. Furthermore, high school teenagers host diwaween within their homes, suggesting that this historic practice appeals to the youth.

While the diwaniya remains very 'Kuwaiti' in nature, it persists as an example of successful heritage, which has continued through time - one that has been preserved by the people themselves. Abdullah Alhajeri defines the diwaniya as "the first democratic institution in Kuwait [where] it is one of the oldest and most deeply rooted social institutions of the Gulf States" (Alhajeri, 2010: 24). Although the diwaniya is a private space, Alhajeri describes it as "the first pseudo-parliament in Kuwait, in which various views could be exchanged with full democracy" (Alhajeri, 2010: 28). Thus one may interpret the diwaniya as a gathering which helps establish a civil society.

\section{The mall}

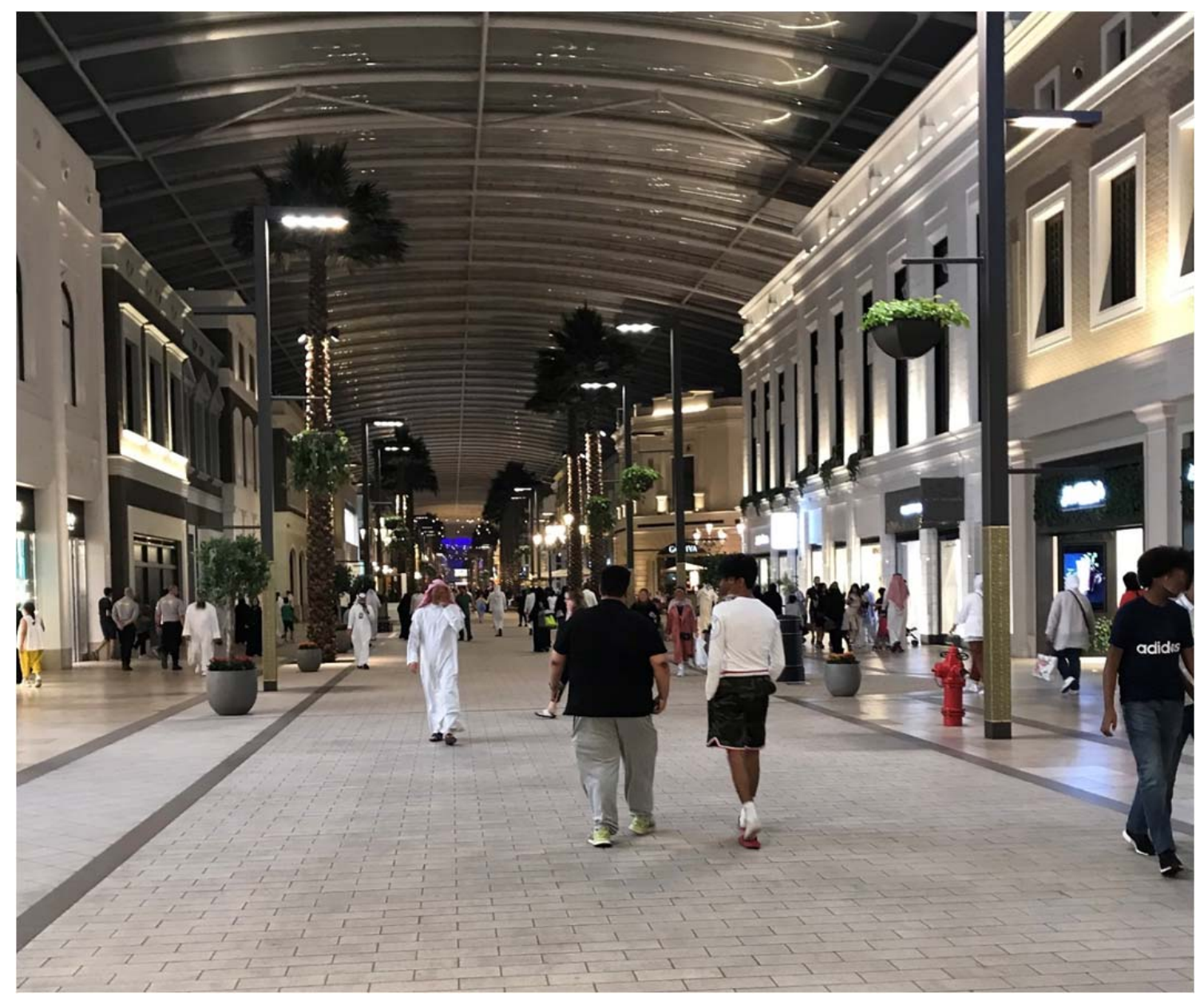

Figure 2. People walking at the Avenues Mall, Rai Area, Kuwait (Photographed by Gareth Doherty)

Generally speaking, malls in the Persian Gulf countries stand as both a social and a capitalist space. This contrasts a vast body of research on malls in urban studies that defines malls as deceptive, controlling, and strictly consumerist spaces, (Crawford, 1995; Goss, 1993; Kohn, 2004; Sorkin, 1999; Zukin, 20I I), neglecting the meaningful social interactions that take place in them. While some may say malls are social spaces everywhere, one can argue that they embody a unique condition in this region. Due to 
the limited nightlife options in Kuwait, along with the extremely hot climate, people utilize the mall as public space, walking and socializing in the shopping mall without necessarily consuming.

This past Ramadan in Kuwait, numerous malls were packed with people exercising and walking during the last couple of hours before breaking fast at futour time (sunset). Since the country lacks shaded public spaces, people resort to malls to shelter themselves from the summer sun. They do not eat or drink at the malls, as the law bans this during fasting hours, and so people do not necessarily spend money.

Even in non-Ramadan days and evenings, people from different classes, ages, and nationalities flock to the malls to get away from the summer heat and walk around (Figure 2). Some malls cater to different classes by having 'luxurious' high-end zones and other more affordable hypermarket areas. Additionally, free parking exists in many malls. Gulf Scholar Rana Al-Mutawa (2018) states that many malls in Dubai "cater to different segments of the population, leading a diverse set of demographics to share the same space (cheap fast food joints and restaurants selling edible gold desserts can be found within the same vicinity)". This resonates with the diverse Kuwaiti social structure.

Also, the male and female gazes, not to mention the security gaze, play a huge role in the mall experience. Ironically, within the socially conservative Kuwaiti context, common mall activities include flirting while walking and people watching. These can result in dating or flirting with no further interaction. The fact that such taboo activities take place here allows people to 'tactically' subvert the social rules. ${ }^{3}$ In the Kuwaiti mall, such activities practiced while walking highlight a sense of working around the panoptic social and security gazes and thereby fighting the system.

\section{Cricket}

Driving around the city on an early Friday morning, one would normally see multiple cricket games taking place throughout the urban area (Figure 3). Cricket games are not exclusive to Kuwait City - they take place in other Gulf cities where there are large numbers of South Asian male workers, like Sharjah in the United Arab Emirates, as well. However, in 2018, the city of Sharjah "banned playing cricket in undesignated areas" (Elsheshtawy, 2018). In Kuwait, these games take place on vacant lots, which are not privately owned but rather are under the government's authority. Numerous games take place simultaneously on some of the vast spaces, with small audiences watching on the peripheries. The players are all young South Asian men. Some are clad in all-white uniforms, some wear formal team jerseys, and others are dressed in casual sportswear attire. Figure 3 shows one of the largest empty lots, standing directly across the street from Al-Shaheed Park, which is the largest urban public park in Kuwait City. The vacant lot is generally flat and empty. A few old buttonwood trees line the boundary of the site, with a larger number on the side bordering the main 'Al-Soor Street'. The site is used for parking during the busy weekdays for people working or visiting the buildings nearby, which include souks like 'Souk Al-Awqaf' and governmental institutions like the Ministry of Interior Affairs.

Sports spaces, in general, are missing from the official parks of Kuwait City. Two-thirds of Kuwait's population are non-Kuwaitis. Asians make up the majority of the population

\footnotetext{
${ }^{3}$ This speaks to Michel de Certeau's notion of tactics.
} 
(Al-lasser 2012; Central Intelligence Agency 2018). Cricket is a very popular game for South Asians in Kuwait, particularly Indians, Bengalis, Pakistanis, and Sri Lankans. Yet, upon reviewing the public spaces and parks of Kuwait City, no designated spaces for such activities can be found. Private sports clubs exist, but the cost of using these spaces is prohibitive for many people. Low-income migrant workers are forced to find places elsewhere. Reem Alissa states, "Migrant worker's spatial practices in Kuwait's publics space subvert [city planners] explicit exclusionary nature, injecting a brief public vision of communities rendered invisible by the official plan of the contemporary state" (Alissa, 2009: 85). I would add that by using empty public lots, not only do these workers emphasize their existence within society, but they do so through their local practices. If anything, they are placemaking in the city.

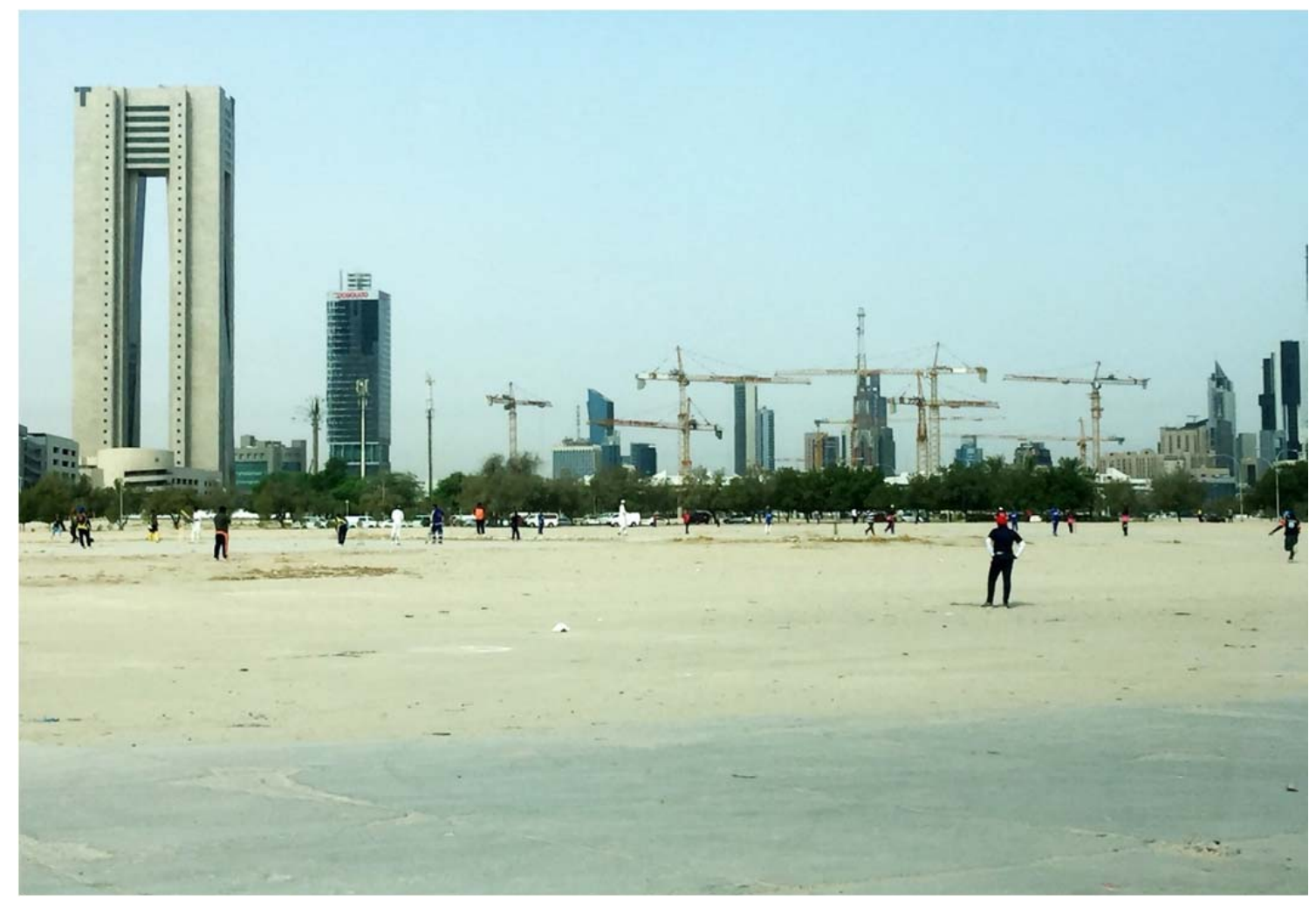

Figure 3. Multiple cricket games taking place on a vacant lot on a Friday morning, Kuwait City, Kuwait (Photographed by Weaam Alabdullah)

\section{Limitations}

While the practices of publicness highlight strong social and political values in society, they are relatively limiting, low-risk, and lacking in diversity since they are mostly private and exclude many publics. The lack of diversity in public spaces is not unique to the Kuwaiti situation (Doherty, 20 I7; Elsheshtawy, 20II, 20I3; Fawaz, 20I6; Kanna, 20II; Salama et al., 2017). Most recently, Maryam Nazzal and Samer Chinder unpacked this in the Lebanese context, where political meetings increasingly occur in private spaces, highlighting the problematic lack of awareness when it comes to the rights of citizens 
(Nazzal \& Chinder, 2018). At a time of increasing consumerism, communities must rethink the reliance on privatization to create spaces for public life.

Public space is essential because malls, residences, and private gathering spaces remain inaccessible to many people and diversity is for the most part absent in these spaces. The cricket spaces highlight this strongly. Income, class, gender, area of living, political ideology and affiliation all come into play. Acceptance into the private settings is bestowed upon those who know about the gathering to begin with, or those who fulfil a certain identity that resembles the identity of the space's owner and crowd/attendees. Most diwaniya and chai ithahha gatherings take place in residential neighbourhoods, and like-minded people, for the most part, attend the same gatherings because each neighbourhood has a certain character. Mary Ann Tétreault and Haya Al-Mughni describe the change in Kuwait's urbanity through time, and when it comes to the postoil neighbourhoods, they state, "The new neighbourhoods introduced new boundaries based on nationality, age cohort, and family status" (I995: 4I2). They describe how some areas closer to the city centre, like Shuwaykh, are primarily occupied by merchant families, and how some neighbourhoods, like Jahra, which are farther away, are housed by Bedouin families (Tétreault \& Al-Mughni, 1995). For the most part, neighbourhoods closer to the city centre, and those adjacent to the sea, are the most expensive. Moreover, an area like Hawalli houses many non-Kuwaitis; other areas may be populated by mostly a singular Muslim sect, like Rumaythiya, which primarily includes Shiite Muslims (Tétreault \& Al-Mughni, 1995). Thus, each neighbourhood has its unique identity based on income, class, religion, nationality and political affiliation. In some conservative neighbourhoods, the diwaniya may exclude women completely or allocate a separate area, and thus women are left out of conversations and confrontations. Lowincome migrant groups are in many ways excluded from both political and social life, congregating instead in vacant lots, streets, and sidewalks (Alissa, 2009). While malls may seem to be more diverse spaces, they still generally cater to the middle and upper classes.

Due to required approval to enter private spaces, and prior knowledge about them, like-minded people end up gathering together, thereby minimizing both risk and struggle, which are necessary in public space. Don Mitchell highlights the importance of embracing struggles in public space, as marginalized groups are seen, represented, heard and become part of the public potentially leading to justice (2003). Farah Al-Nakib argues that malls are a "prime venue for antisocial behaviour" which lack diversity (2016: 4). She also states that malls are "anything but public ... 「they] do not foster any type of social public interaction or exchange other than economic exchange" (Al-Nakib, 2017). While I disagree with Al-Nakib on the non-existence of social interaction in malls, I agree with the fact that these spaces are anything but public because they do not allow the physical representation of 'others' and thus lack diversity. This past 'Eid Al-Fitr, I was walking in a grand shopping mall in Dubai when I saw a security guard stop five young, South Asian, working-class men from entering the 'luxury' area. A large South Asian migrant workforce exists in the Gulf countries. While all areas of the mall flow into one another, and while no physical barriers signify approval for entry, the guard became that barrier. The appearance of these young men did not appeal to 'the mall,' thereby leading to their exclusion. Scenarios like this demonstrate the segregation 
enforced in spaces like malls, while private spaces add another layer of exclusivity to social life in Kuwait.

Framing malls as public spaces minimizes the importance of actual public spaces like parks, which are undeniably spaces of representation. Mitchell states that "[struggle] is the only way that the right to public space can be maintained and [the] only way that social justice can be advanced" (2003: 5). Thus, the actions and occupation of a particular space make it public. This highlights the need for democratic public spaces like parks, which increase in value as time elapses and a broader range of interactions are facilitated.

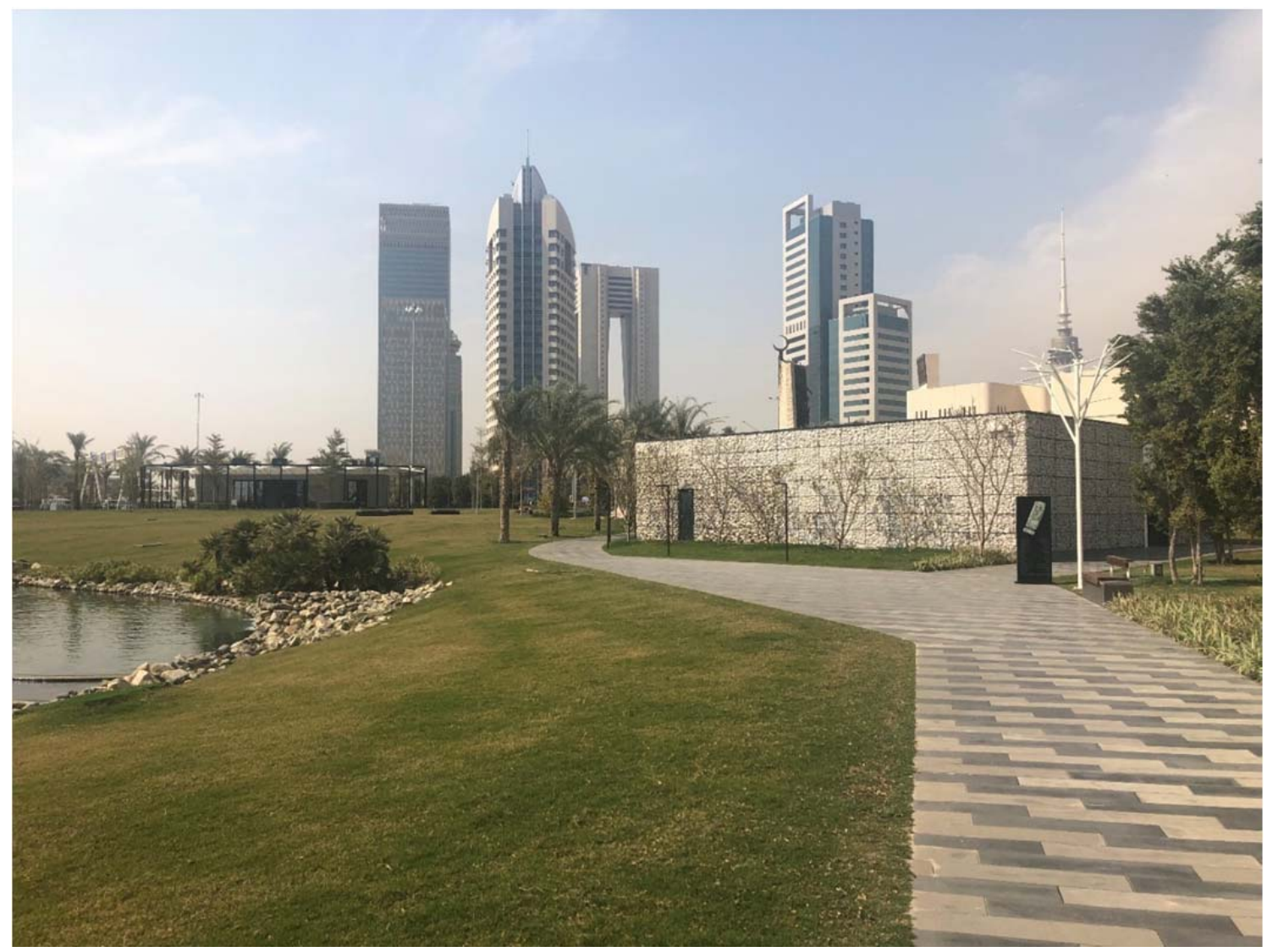

Figure 4. Al-Shaheed Park, Kuwait City, Kuwait (Photographed by Weaam Alabdullah)

All four practices highlight simple requirements for public space. They require plenty of room for gathering or playing sports; shade; basic services like restrooms; food and drinks; and a safe, non-judgmental environment. Incorporating these necessities in parks may allow for the representation of more publics, leading to the creation of public spaces that both respond to this particular locality and allow for greater access. While the private residences and malls will probably continue to exist and cater to their particular audience, one questions what will happen to the cricket games once development takes over the cricket sites.

If one were to look at Kuwait's existing public spaces, they fall under two categories: first, the derelict spaces, and secondly, the overly controlled spaces. The derelict spaces include neighbourhood parks, public beaches, and vacant sites. The overly controlled 
spaces include newer public projects such as Al-Shaheed Park (Figure 4), which is funded by the Emir's Council. Public spaces under both categories generally don't include areas for sports or larger social gatherings, or sufficient shading. Thus, existing public spaces fall short from addressing basic needs.

\section{Parks}

The public park came into being with democratic societies, emerging in the 1830 s as a result of a desire to improve urban conditions in Europe and the United States. Frederick Law Olmsted questioned how the United States could create parks that improved such issues and also reflected democratic political and social values. While Kuwait is a semi-democratic country, public parks can help expand publics and allow for co-existence due to their openness, not to mention centrality within urban settings. Yet, not enough parks exist in Kuwait City, especially parks that cater to people's needs. While some may argue that summers in Kuwait are hot and people would rather seek shelter indoors, I would argue that many public spaces are nocturnal during the summer. Besides, landscape architects may begin to rethink human comfort in extreme arid public landscapes creating an opportunity for social bridging. Also, Kuwaiti public spaces may be more actively used in the winter, similarly to parks in colder climates that are primarily used in the summer.

Public spaces and particularly parks have the potential to become a platform for the four practices while respecting the multiple cultures overlapping in this space. Parks exist as more than spaces of nature but as spaces of representation and risk. In Large Parks, Julia Czerniak and George Hargreaves (2007) understand parks as complex cultural spaces. James Corner highlights the "profound cultural and ecological virtues" of parks where they 'function as 'green lungs,' cleaning, refreshing, and enriching life in the metropolis" (2007: II). Elizabeth Meyer (2007) reframes parks as spaces that work with difference, diversity, difficulties, and risk. The idea of risk can mean taking social risks in the hopes of enlightening a community. Parks stand as public spaces of awareness and recognition, provoking citizens to think and act. Meyer states that using 'disturbed sites,' which one can understand as physically and/or socially disturbed, as parks, "resurrects the park's agency as a vehicle for engendering new connections between private actions and public values, between individuals and the world" (2007: 75). Parks may highlight hidden battles, bringing them to the forefront and allowing for the construction of public opinions around them. For example, a hidden battle could exist between conservative and liberal Kuwaitis based on the concept of mixed-gender gatherings at the park. Earlier this month, a conservative parliamentary member deemed dancing at a concert an immoral act, which affects Kuwaiti society (Al Sherbini, 20 I9). In February, several Islamist parliamentary members questioned the government about a dancing event at the Mubarkiya Souk in Kuwait City, which they suggested was violating 'the system' (Alanba, 2019). Awareness of these issues in public spaces could allow other people to speak up. Would this happen at the mall? Maybe, but most probably not, as security would immediately involve themselves before letting this issue escalate. The constructed environment performs as the terrain for political action, increasing its political agency. Representation reveals something hidden, which allows social risk to increase, possibly allowing people to act. This can mean considering others when taking 
political actions in the future. Furthermore, the park becomes a site for multiple practices to take place simultaneously, allowing others to acknowledge their existence. A park design project stemming from existing practices and the notion of risk can empower members of the community and perhaps lead them to act on issues affecting the larger society. In Kuwait, this can mean bringing publics that were not brought together before and this works across different scales from the macro to the micro. At the metropolitan scale, choosing sites in more urban settings rather than suburban areas may allow more 'publics' to converge. Many of Kuwait's present parks exist in suburban neighbourhoods that are primarily composed of Kuwaiti residents. Within the park's scale, allowing different programs that are not typically close in proximity to exist in the same place, may increase the appearance and awareness of multiple publics. For example, cricket and soccer areas, barbeque areas, and kids play areas could exist in the same park. By seeing people who one wouldn't usually be around, i.e. those from different social groups, genders, ages, classes or nationalities, one becomes aware of the real composition of society. However, this does not mean that all these publics must interact or gather together. The park simply creates opportunities.

Cricket is largely popular amongst the South Asian male community, while soccer attracts a huge multi-national group of people. Nevertheless, existing parks lack spaces that support these sports. Barbequing used to take place on the weekends alongside public beaches by numerous expatriates. Then, the municipality prohibited barbequing in public space in 20I5, arguing that they affect the cleanliness and aesthetic of public facilities (Saleh, 20I5). A park that combines all of these activities simultaneously may allow moments of reflection where people start to question the prohibition of public barbeques and acknowledge Kuwait's societal diversity, its diverse interests, and needs. It allows people to question the discrimination within the system and have space to comment on it. As a semi-democratic country, people have the right to change rules like this. An urban park could be flanked with small, open buildings or pavilions that serve as chai ithahha tea rooms in the morning and as diwaween in the evening. It can have large empty spaces for cricket games on Friday mornings that can transform into spaces for soccer games in the weekday evenings. The incorporation of such practices through the lens of social risk and cultural sensitivity simultaneously would accommodate publics from multiple classes, genders, nationalities and income groups, and it would start to uniquely frame parks in Kuwait.

At the micro-scale, focusing on seating may also allow more inclusivity. Laurie Olin (2017) emphasizes the utility of public seating in affecting our role as citizens in a city. Benches and chairs arise as the setting for simple yet significant aspects of daily life, especially for underrepresented groups. The designing of benches begins to deal with heterogeneity and specifically issues of lack of recreational space for underrepresented low-income groups such as the South Asian migrant workers who are not allowed access to the mall.

A simple reframing of where a design project starts from can alter the meaning of a public space, defining it as a space where a whole society rethinks their values, and which reproduces citizens who not only think, but act. Imagine the shift in national mind-set that might occur if more parks facilitated diverse interactions amongst people of different race, class, age, religion, and gender. Where a mall remains a consumer space with little representation, the park challenges its users to be more conscious citizens. The mall does not suffice. The blurry public-private status of the mall traps a 
consumer in the world of capitalism and consumption. Similarly, the semi-public nature of the diwaniya and chai ithahha gatherings creates an unrealistic representation of chosen participants that do not symbolize the numerous publics in society. Public spaces cannot fix societal problems, rather they can reckon with and reveal them, and this in itself creates potential in dealing with disputes and differences and maybe even creating more resilient citizens.

\section{Conclusion}

Parks founded on practices of publicness can recreate a distinct sense of place and become catalysts for new publics and communities because they stem from the needs of multiple groups of people. Public space literature highly affects landscape architecture as a practice, yet, the four practices, amongst others in different geographies, do not fall under accepted discourses of public space. Their absence from the literature affects landscape architecture and particularly park projects. Bringing forth such activities within the literature may allow a change in the design of parks, increasing their potential in placemaking.

Unpacking the four practices in one conversation highlights the importance of rethinking meaningful yet exclusive activities in parks to benefit more people. Parks that acknowledge and work with such practices may allow more people and societal issues to 'appear'. Some tensions would no longer be hidden, allowing people to have a say about them. Perhaps then, new hope, new politics, and multiple publics, as opposed to only a singular 'public', can emerge. This has major implications on the politics of a given society, creating an infrastructure to support future action. All of this matters because it allows us to rethink public space theory, static design methods and the scope of design, as well as understand that cities may benefit tremendously from constructed spaces of nature that take into consideration a specific society's practices of publicness. Such parks stand as more than recreational open spaces. Potential exists in the expansion and reproduction of citizenship in these spaces, where one foresees an inclusion of more people as citizens in a city. Landscape architects can use people's practices as inspiration to create parks that take cultural forms restricted to the economically privileged and (for the most part) Kuwaiti citizens and flip this formula upside down. Doing this would create spaces that allow more people to be visible and take action, while also maintaining the cultural identity of the place and allowing people to do what they want. An example of this is the Cross Cultural Diwaniya, "a monthly discussion forum where local residents gather to discuss and debate topics of importance relating to the community - including social, political, and economic issues in a multilateral and open environment" (Cross Cultural Diwaniya 20I3). Topics range from censorship to women's rights, to voting and more. This takes place in Masaha 13, a privately owned art-infused community space composed of a library, gallery space, and café. How would a plethora of diwaniyas and chai ithahha gatherings perform in the park - a more open and inclusive space?

The challenge is not to create a park of a unified whole where people must talk to one another, but to find design alternatives that speak to multiple publics. This occurs while working with the publics' wants and needs, as well as the place's complex identity. The Superkilen project in Copenhagen, Denmark represents, under the premise of 
supporting diversity, a utopian idea where design can fix social limitations and foster community immediately. The design celebrates symbols from multiple religions and cultures within a half a mile long urban space that spans across ethnically diverse neighborhoods in Copenhagen. One might question whether a direct rather superficial symbolic translation of one's religion leads to immigrants feeling at home in this Scandinavian context. One also might question how 'heterogeneity' is taken up in the research and investigation part of any design process. Incorporating richer existing practices within a given place that speak to people's needs may bring social problems forward to our attention, allowing different publics to speak about them, and instigate action around them. Understanding that gender segregation at times is necessary and preferred for certain groups of people is important, and working with that rather than against it becomes crucial. How would the political debates in a park diwaniya differ, where the men can still be separated from women and migrant workers, but still see them upon entering the site, walking around or playing sports? How would this affect who they acknowledge and assume to be part of society during their conversation and political actions? How would the park chai ithahha debates differ, where the women are having tea without the male gaze, yet the men can be seen outside and acknowledge their existence? How would the mixed-gender diwaniya seem to people passing by? While the diwaniya, chai ithahha, the mall, and cricket spaces may be understood as 'spaces of appearance' (Arendt 1958), I consider how to expand 'the public' into 'publics' through public space theory and design to include more participants but without enforcing a foreign ideology of what a public space or park is. I argue that one ought to focus on practices of publicness unique to each context, both in the literature and practice, as this affects placemaking practices.

One may argue that the four practices discussed in this paper are exclusive because people participating in them want to exclude others. Hence, we must turn to parks in cities as a space for shared experience and diversity in the face of radical capitalism and segregation. I do not wish to suggest that gatherings should be forced into public spaces. Rather, I argue that creating opportunities for public space gatherings allows for a more realistic representation of publics, allowing different people to acknowledge and/or respond to them.

\section{References}

Al Sherbini, R. (2019). 'Video: Kuwaitis dance at concert sparking outrage from conservatives', Gulf News, 2 I October. Retrieved from: https://gulfnews.com/world/gulf/kuwait/video-kuwaitisdance-at-concert-sparking-outrage-from-conservatives-1.67279894 (Accessed: 29 October 2019).

Alenazy, T. (2007). 'The Privacy and Social Needs of Women in Contemporary Kuwaiti Homes'. MFA thesis, Florida State University, Tallahassee.

Alhajeri, A. (20I0). The development of political interaction in Kuwait through the "Diwaniyas" from their beginnings until the year 1999. Journal of Islamic Law and Culture, I2(I), pp. 24-44.

Alissa, R. (2009). Modernizing Kuwait: Nation-building and Unplanned Spatial Practices. Berkeley Planning lournal, 22, pp. 85-9I.

Almutairi, T. M., \& Kruckerberg, D. (2019). Public relations in the Gulf cooperation council countries: an Arab perspective. New York, Routledge.

Alsayer, D. (2014). 'From Domestic Housh to Consumer Mojama'a: The Social Space of Women in Kuwait'. Magazine On Urbanism [MONU]. October, pp. 26-33. 
Alhabib, E. (2009). 'A Study on Diwaniyas and Their Social and Political Impact on the Kuwaiti Society'. Master thesis, American University, Washington.

Arendt, H. (1958). The Human Condition. Chicago: University of Chicago Press.

Atifa, N. (2013). 'File of the Week', Al-Watan Newspaper, IO March. Retrieved from: http://alwatan.kuwait.tt/articledetails.aspx?id=259206\&yearquarter=2013। (Accessed: 15 October 2019).

Al-Ansari, M. (2016). 'Masked in the Protective Act: Women, Public Housing \& the Construction of "Modern/National" Identities in Kuwait'. PhD thesis, University of Cincinnati, Cincinnati.

Al-Jassar, M. (2009). 'Constancy and Change in Contemporary Kuwait City: The Socio-Cultural Dimensions of the Kuwaiti Courtyard and Diwaniyya'. PhD thesis, University of Wisconsin, Milwaukee.

Al-Jasser 20I2, H. (20I2). '2/3 Kuwait Population Foreign, Half from Indian Subcontinent'. AlMonitor, 2 April. Retrieved from: https://www.al-monitor.com/pulse/business/2012/04/two-thirdsof-the-kuwaiti-popula.html (Accessed: 29 October 2019).

Al-Mutawa, R. (2018). 'Challenging Concepts of 'Authenticity': Dubai and Urban Spaces in the Gulf. The London School of Economics and Political Science Middle East Centre Blog, 4 December. Retrieved from: https://blogs.Ise.ac.uk/mec/2018/I2/04/challenging-concepts-ofauthenticity-dubai-and-urban-spaces-in-the-gulf/ (Accessed: 25 October 2019).

Al-Nakib, F. (2016). Kuwait Transformed: A History of Oil and Urban Life. Stanford, CA: Stanford University Press.

Al-Nakib, F. (2017). 'Panel I: Nocturnal Activities in Public Spaces'. After Dark: Nocturnal Landscapes and Public Spaces in the Arabian Peninsula. The Graduate School of Design, Harvard University, Cambridge. 7-8 April.

Al-Soula, A. (2013) 'File of the Week', Al-Watan Newspaper, 10 March. Retrieved from: http://alwatan.kuwait.tt/articledetails.aspx?id=259206\&yearquarter=2013I (Accessed: 15 October 2019).

Bravo, L. (2018). We the public space. Strategies to deal with inequalities in order to achieve inclusive and sustainable urban environments. The Journal of Public Space, 3(I), pp. I63-I64. DOI: 10.5204/ips.v3il.326.

Central Intelligence Agency. (2018). 'The World Factbook: Kuwait', viewed 29 October 2019, <https://www.cia.gov/library/publications/the-world-factbook/geos/ku.html>

Chai Ithahha. (2019). Television Broadcast. Kuwait Television Channel I, Kuwait City, Kuwait.

Clemens, C. (20I6). The Dīwāniyya Tradition in Modern Kuwait: An Interlinked Space and Practice. lournal of Arabian Studies, 6(I), pp. I-28.

Cowan, B. W. (2005). The Social Life of Coffee: The Emergence of the British Coffeehouse. New Haven: Yale University Press.

Corner, J. (2007). 'Forward', in Czerniak, J., \& Hargreaves, G. (ed.) Large parks. New York, Princeton Architectural Press.

Cross Cultural Diwaniya. (20/3). 'Cross Cultural Diwaniya: Elevating Conversations', viewed 23 October 2019. <https://www.ccdkw.me/>

Czerniak, I., \& Hargreaves, G. (2007). Large parks. New York, Princeton Architectural Press.

Doherty, G. (2017). Paradoxes of Green: Landscapes of a City-State. Oakland, California: University of California Press.

Elsheshtawy, Y. (20I I). Informal Encounters: Mapping Abu Dhabi's Urban Public Spaces. Built Environment (1978- ), 37(I), pp. 92-II3.

Elsheshtawy, Y. (20I3). Where the sidewalk ends: Informal street corner encounters in Dubai. Cities, 3I, pp. 382-393.

Elsheshtawy, Y. (2018). 'No Cricket, No Play: Regulating Public Space in Gulf Cities', The Arab Gulf States Institute in Washington, 7 June. Retrieved from: https://agsiw.org/no-cricket-no-playregulating-public-space-gulf-cities/ (Accessed: 23 October 2019). 
Fawaz, M. (2016). Reframing the debate to save what is left of Beirut's shrinking seafront. The Lebanese Center for Policy Studies, October. Retrieved from http://lcpslebanon.org/featuredArticle.php?id=90 (Accessed: 28 October 2019).

Goss, J. (1993). The "Magic of the Mall": An Analysis of Form, Function, and Meaning in the Contemporary Retail Built Environment. Annals of the Association of American Geographers, 83(I), pp. 18-47.

Habermas, J. (1962). The Structural Transformation of the Public Sphere: An Inquiry into a Category of Bourgeois Society. Cambridge: Polity Press.

Kanna, A. (20I I). Dubai, the City as Corporation. Minneapolis: University of Minneapolis Press.

Meyer, Elizabeth. (2007). 'Uncertain Parks: Disturbed Sites, Citizens, and Risk Society', in Czerniak, J., \& Hargreaves, G. (ed.) Large parks. New York, Princeton Architectural Press.

Mitchell, D. (2003). The Right to the City: Social Justice and the Fight for Public Space. New York: Guilford Press.

Nazzal, M. and Chinder, S. (2018). Lebanon Cities' Public Spaces. The Journal of Public Space, 3(I), PP. II9-I52. DOI: 10.5204/jps.v3il.323.

Olin, L. (2017). Be Seated. San Rafael: Oro Editions.

Salama, A. M., Azzali, S. \& Wiedmann, F. (2017). The everyday urban environment of migrant labourers in Gulf Cities: the case of the old centre of Doha, Qatar. City, Territory and Architecture, 4(5).

Saleh, A. (2015). 'Barbeque ban on pavements, streets and public parks and seafronts', Kuwait Times, 28 December. Retrieved from: https://news.kuwaittimes.net/website/barbeque-banon-pavements-streets-and-public-parks-and-seafronts/ (Accessed: 21 October 2019).

Tétreault, M., \& Al-Mughni, H. (1995). Modernization and Its Discontents: State and Gender in Kuwait. Middle East Journal, 49(3), pp. 403-4I7. 